\title{
Development of Learning Tools with Learning Videos Using the Flipped Classroom Approach on Gas Kinetic Theory Material in Class XI SMA
}

\author{
Sukma Raviasta ${ }^{* 1)}$, Zulhelmi ${ }^{2)}$, Zuhdi Maaruf ${ }^{3)}$ \\ ${ }^{1,2,3)}$ Physics Education, University of Riau \\ email: ${ }^{* 1)}$ sraviasta@gmail.com \\ emi_zain@yahoo.co.id \\ zuhdi.maaruf@lecturer.unri.co.id
}

\begin{abstract}
This research's goal was to develop learning tools with video using a flipped-classroom approach which is valid on the kinetic theory of gas for students in class XI MIPA SMA. This research uses a research and development method with the ADDIE development model (analysis, design, development, implementation, and evaluation), which in this research is limited to the development phase. The research instrument used was a problem-fulfillment questionnaire filled out by students and a validation assessment sheet that was filled in by a validator. The data collection technique was based on the results of filling out a questionnaire by students at SMA N 1 Pekanbaru and from the validation analysis sheet by the validator. The data analysis technique used the percentage method and continued with data validation using descriptive analysis. This research produces learning tools in the form of lesson plans, student worksheets, and learning videos. The results of the assessment of learning tools using the flipped classroom approach obtained an average value for lesson plans with a very high category value of 4.36, video learning with a value of 4.56 in the very high category, and LKPD with a score of 4.2 very high categories. Each assessment indicator has a value greater than 3, and the validity value is declared valid. Thus, the learning device using video media using the flipped-classroom approach to the kinetic theory material of gas for students of class XI MIPA SMA is declared to be valid and suitable for use.
\end{abstract}

Keywords: flipped-classroom, learning tools, learning videos. 


\title{
Pengembangan Perangkat pembelajaran dengan Video Pembelajaran Mengunakan Pendekatan Flipped Classroom pada Materi Teori Kinetik Gas di Kelas XI SMA
}

\author{
Sukma Raviasta ${ }^{1)}$, Zulhelmi ${ }^{2)}$, Zuhdi Maaruf ${ }^{3)}$ \\ 1,2,3) Pendidikan Fisika, Universitas Riau
}

\begin{abstract}
Abstrak
Penelitian ini bertujuan untuk mengembangkan perangkat pembelajaran dengan video menggunakan pendekatan flipped-classroom yang valid pada materi teori kinetik gas untuk peserta didik kelas XI MIPA SMA. Penelitian ini menggunakan metode research and development dengan model pengembangan ADDIE (analysis, design, development, implementation, and evaluation), yang mana pada penelitian ini dibatasi sampai pada tahap development. Instrumen penelitian yang digunakan ialah angket pemenuhan kebutuhan masalah yang diisi oleh peserta didik dan lembar penilaian validasi yang diisi oleh validator. Teknik pengumpulan data berdasarkan hasil pengisian angket oleh peserta didik di SMA N 1 Pekanbaru dan dari lembar penialaian validasi oleh validator. Teknik analisis data menggunakan metode persentase dan dilanjutkan dengan validasi data menggunakan analisis deskriptif. Penelitian ini menghasilkan perangkat pembelajaran berupa RPP, LKPD, dan video pembelajaran. Hasil penilaian perangkat pembelajaran dengan pendekatan flipped-classroom diperoleh nilai rata-rata untuk RPP dengan nilai 4,36 kategori sangat tinggi, video pembelajaran dengan nilai 4,56 kategori sangat tinggi, dan LKPD dengan nilai 4,2 kategori sangat tinggi. Setiap indikator penilaian memiliki nilai lebih besar dari 3, dan nilai validitas dinyatakan valid. Dengan demikian, perangkat pembelajaran dengan media video menggunakan pendekaan flipped-classroom pada materi teori kinetik gas untuk peserta didik kelas XI MIPA SMA dinyatakan valid dan layak untuk digunakan.
\end{abstract}

Kata Kunci: flipped-classroom, perangkat pembelajaran, video pembelajaran.

\section{Pendahuluan}

Berdasarkan Undang-Undang no. 20 tahun 2003, "Setiap warga negara memiliki hak yang sama untuk memperoleh pendidikan yang bermutu". Karena itu, Indonesia sebagai suatu Negara wajib melaksanakan proses pembelajaran. Melalui undang-undang tersebut juga dicantumkan bahwa proses pembelajaran merupakan usaha sadar dan terencana untuk mewujudkan suasana belajar dan proses pembelajaran agar peserta didik aktif dalam mengembangkan potensi dirinya (RI, 2003). Perkembangan pendidikan pada saat ini sangat pesat dengan adanya bantuan teknologi seperti mudahnya akses informasi yang diperoleh peserta didik ataupun guru dengan bantuan internet. Akses internet yang universal memungkinkan siapa pun dapat mencari, memperoleh, dan menambahkan informasi (Hefzallah, 2004). Sehingga, pembelajaran dalam sistem pendidikan tidak hanya pertemuan di ruang kelas saja. Pembelajaran dapat dilakukan dirumah, bahkan ditempattempat umum sekarang sudah bisa menjadi tempat dalam pembelajaran.

Video Pembelajaran menjadi salah satu bukti perkembangan teknologi yang mempengaruhi perkembangan pendidikan. Menurut Azhar (2011) video merupakan kumpulan gambar dalam frame yang diproyeksikan melalui lensa proyektor secara mekanis sehingga pada layar terlihat gambar hidup. Video dapat diartikan sebagai salah satu jenis media yang dapat meningkatkan daya tarik atau minat orang yang melihatnya. Berdasarkan penelitian oleh Yunita \& Wijayanti (2017) di SMP Negeri 1 Turi diperoleh rerata hasil belajar IPA pada kelompok yang diajar dengan menggunakan media video yaitu 20,78 dan rerata yang diperoleh untuk kelompok yang diajar tanpa menggunakan media video hanya 14,78. Hal tersebut disebabkan kelompok yang diajar dengan media video lebih termotivasi, 
sehingga meningkatnya rasa keingintahuan peserta didik.

Penggunaan media pembelajaran video tentu memerlukan waktu lebih lama, apabila guru memutar video pada saat di kelas, tetapi akan lebih optimal jika penggunaan media ini dengan memanfaatkan pendekatan flipped classroom. Berdasarkan penelitian yang dilakukan oleh Saputra (2018) menghasilkan penggunaan pendekatan Flipped classroom dengan menggunakan video pembelajaran pada siswa lebih baik dan efektif dalam pemahaman konsep dari pada hanya menggunakan metode ceramah, hal ini ditunjukkan dengan hasil taraf nyata kajian sebesar 0,05. Flipped classroom adalah pembelajaran yang membalik kebiasaan siswa yang dilakukan di kelas dan di rumah. Kebiasaan yang diselenggarakan di kelas seperti penyajian materi oleh guru menjadi kegiatan yang dilakukan di luar kelas atau dirumah sedangkan, mengerjakan soal-soal yang dijadikan pekerjaan rumah, menjadi perkerjaan yang dikerjakan di kelas (Bergman \& Sams, 2012; William et al., 2018).

Berdasarkan buku flipped with krich yang ditulis oleh Krich terdapat perbedaan yang sangat dramatis setelah sekolah Clintondale High School menerapkan pembelajaran berbasis flipped classroom, dimana peningkatan tersebut berupa jumlah siswa yang gagal pada sebuah mata pelajaran terdapat hanya $19 \%$ peserta didik yang gagal pada materi bahasa ingris dan $13 \%$ yang gagal pada matematika dengan pendekatan flipped classroom, sedangkan pada pembelajaran konvensional terdapat $50 \%$ peserta didik yang gagal pada mata pelajaran bahasa ingris dan $44 \%$ gagal pada mata pelajaran matematika (Brent, 2013).

Pemanfaatan pembelajaran dengan pendekatan flipped classroom ini bisa digunakan pada pembelajaran fisika terutama pada materi teori kinetik gas. Materi pembelajaran fisika tentang teori kinetik gas merupakan salah satu materi yang sulit disampaikan oleh guru secara langsung di kelas, hal ini dikarenakan banyaknya sub bab atau materi pembelajaran yang harus disampaikan, dan sulitnya manganalogikan materi pembelajarannya. Hal ini dapat dilihat pada hasil belajar siswa sebagian besar belum mencapai nilai kriteria ketuntasan minimal $(\mathrm{KKM})$. Perolehan nilai ulangan kompetensi dasar di SMA Santo Bonaventura ditemukan hanya $12,5 \%$ yang melampaui KKM, sedangkan pada MAN Sambas diperoleh persentase 26,3 \% (Jaka, 2016).

Berdasarkan latar belakang yang telah diuraikan, maka dalam kajian ini perlu dikembangkan perangkat pembelajaran yan dilengkapi dengan media video pembelajaran menggunakan pendekatan flipped classroom pada materi teori kinetik gas bagi peserta didik kelas XI MIPA Sekolah Menengah Atas.

\section{Metode Penelitian}

Penelitian ini menggunakan metode $\mathrm{R} \&$ $\mathrm{D}$ (Reaserch and Development) dengan model pengembangan ADDIE (Analysis, Design, Development, Implementation, and Evaluation) melalui pendekatan flipped classsrom. Pelaksanaan penelitian dilakukan hanya sampai pada tahap development atau pengembangan saja untuk menghasilkan produk perangkat pembelajarani dan divalidasi oleh validator untuk menghasilkan produk yang valid. Tahapan model pengembangan ADDIE yaitu: tahap analisis (Analysis), dilakukan analisis keperluan terkait masalah peserta didik tentang pembelajaran fisika pada materi teori kinetik gas. Pengumpulan informasi dilakukan dengan pemberian angket kepada peserta didik.

Selanjutnya pada tahap desain, dilakukan proses mendesain perangkat pembelajaran berupa RPP, desain video pembelajaran berupa storyboard, dan lembar kerja peserta didik (LKPD) pada materi teori kenetik gas. Tahap berikutnya pengembangan, proses pembuatan RPP, LKPD dan video pembelajaran. Setiap tahapan dilakukan evaluasi, mulai dari tahap analisis untuk dilakukan perbaikan terhadap kekurangan perangkat yang dikembangkan. Selanjutnya dilakukan validasi perangkat oleh validator untuk menilai produk yang dibuat apakah sudah valid atau belum.

Teknik pengumpulan data dilakukan dengan cara pengisian angket sebagai analisis masalah oleh peserta didik, pengisian lembar validasi oleh validator oleh 3 orang ahli materi dan media dari dosen pendidikan fisika sesuai bidang keahliannya. Penggunaan kuisioner digunakan sebagai analisis masalah dengan menggunakan metode persentase, dan dilanjutkan dengan validasi data dengan menggunakan 
analisis deskriptif (teknik yang mengkonversikan data kualitatif menjadi data kuantitatif) (Sugiyono, 2012).

Langkah-langkah yang digunakan untuk menentukan validitas perangkat dan media pembelajaran flipped classroom yang pertama ialah menjumlahkan nilai setiap indikator lembar penilaian validitas. Skala penilaian lembar validitas disajikan pada Tabel 1 .

Tabel 1. Kategori penilaian lembar validasi

\begin{tabular}{clc}
\hline No & \multicolumn{1}{c}{ Kategori } & Skor \\
\hline 1 & Sangat Setuju & 5 \\
2 & Setuju & 4 \\
3 & Ragu-ragu & 3 \\
4 & Tidak Setuju & 2 \\
5 & Sangat Tidak Setuju & 1 \\
\hline
\end{tabular}

Sumber: (Djaali dan Pudji, 2008).

Dilanjutkan dengan mencari nilai rata-rata tiap indikator dengan menghitung jumlah pernyataan yang diberikan oleh validator berdasarkan Tabel 1, dan mencari rata-rata untuk setiap pernyataan. Lalu menentukan kategori nilai rata-rata indikator sesuai ketentuan pada Tabel 2.

Tabel 2. Kategori nilai rata-rata indikator

\begin{tabular}{cll}
\hline $\begin{array}{c}\text { Skor Rata- } \\
\text { Rata }\end{array}$ & \multicolumn{1}{c}{ Kategori } & \multicolumn{1}{c}{ validitas } \\
\hline $4,00<\bar{X} \leq 5,00$ & $\begin{array}{l}\text { Sangat } \\
\text { Tinggi (ST) }\end{array}$ & valid \\
$3,00<\bar{X} \leq 4,00$ & Tinggi (T) & valid \\
$2,00<\bar{X} \leq 3,00$ & Rendah (R) & tidak valid \\
$1,00<\bar{X} \leq 2,00$ & Sangat & tidak valid \\
& Rendah (SR) & \\
\hline
\end{tabular}

Perangkat pembelajaran berupa RPP, Video pembelajaran, dan LKPD dikatakan valid apabila semua indikator penilaian berada pada kategori tinggi (T) dan sangat tinggi (ST) dengan nilai validitas valid. Jika terdapat salah satu indikator penilaian yang tidak valid, maka dilakukan validasi ulang sampai memenuhi kriteria valid dan layak digunakan.

\section{Hasil Dan Pembahasan}

Penelitian ini menghasilkan produk perangkat pembelajaran berupa RPP dilengkapi video pembelajaran dan LKPD dengan pendekatan flipped classroom. Berdasarkan tahap analisis didapatkan hasil analisis masalah pada pembelajaran teori kinetik gas dapat dilihat pada Tabel 3.

Tabel 3. Hasil analisis kesulitan belajar peserta didik dan ketertarikan pada video pembelajaran

\begin{tabular}{llc}
\hline \multicolumn{1}{c}{ Pernyataan } & \multicolumn{1}{c}{$\begin{array}{c}\text { Hasil Kuisioner } \\
(\%)\end{array}$} \\
\hline $\begin{array}{l}\text { Kesulitan belajar peserta } \\
\text { didik pada materi teori } \\
\text { kinetik gas }\end{array}$ & Sulit & 67 \\
$\begin{array}{l}\text { Ketertarikan peserta } \\
\text { didik terhadap } \\
\text { pembelajaran berbasis }\end{array}$ & Tertarik & 91 \\
$\begin{array}{l}\text { internet dan video } \\
\text { sebagai media } \\
\text { pembelajaran }\end{array}$ & Terarik & 9 \\
\hline
\end{tabular}

Tabel 3 terlihat bahwa, terdapat kesulitan belajar pada materi teori kinetik gas yang dialami peserta didik sebesar $67 \%$. Hal ini menunjukkan bahwa perlu diberikan perlakuan untuk mengurangi kesulitan belajar peserta didik tersebut. Sedangkan ketertarikan terhadap pembelajaran berbasis internet/video ternyata $91 \%$ peserta didik menyatakan tertarik.

Tahap desain dari perangkat pembelajaran dengan pendekatan flipped classroom berbantukan video pembelajaran menggunakan berbagai aplikasi yang terlihat pada Tabel 4 .

Tabel 4. Aplikasi yang digunakan dalam pembuatan produk pengembangan

\begin{tabular}{|c|c|}
\hline Produk & Aplikasi Yang Digunakan \\
\hline RPP & Microsoft word \\
\hline $\begin{array}{l}\text { Video pem- } \\
\text { belajaran }\end{array}$ & $\begin{array}{l}\text { Adobe Premier Pro, } \\
\text { Adobe Photoshop, } \\
\text { Adobe Macromedia Flash, } \\
\text { dan You Tube }\end{array}$ \\
\hline LKPD & Microsoft word \\
\hline
\end{tabular}


Selanjutnya ke tahap pengembangan untuk semua produk berupa RPP, video pembelajaran, dan LKPD. Hasil dari pembuatan video pembelajaran dapat dilihat di You Tube pada channel akun Sukma Raviasta seperti pada Gambar 1. Tampilan awal video seperti pada Gambar 2.

Video pembelajaran dapat digunakan oleh peserta didik sebelum proses pembelajaran dimulai di kelas yang bisa ditonton kapan saja dan dimana saja baik menggunakan koneksi internet ataupun tidak. Pendekatan pembelajaran dengan flipped classroom menjadi salah satu solusi dari berbagai kesulitan yang dihadapi peserta didik. Pendekatan flipped classroom memiliki penyediaan waktu dan fleksibilitas pada tempat belajar (Ozdamli \& Asiksoy, 2016).

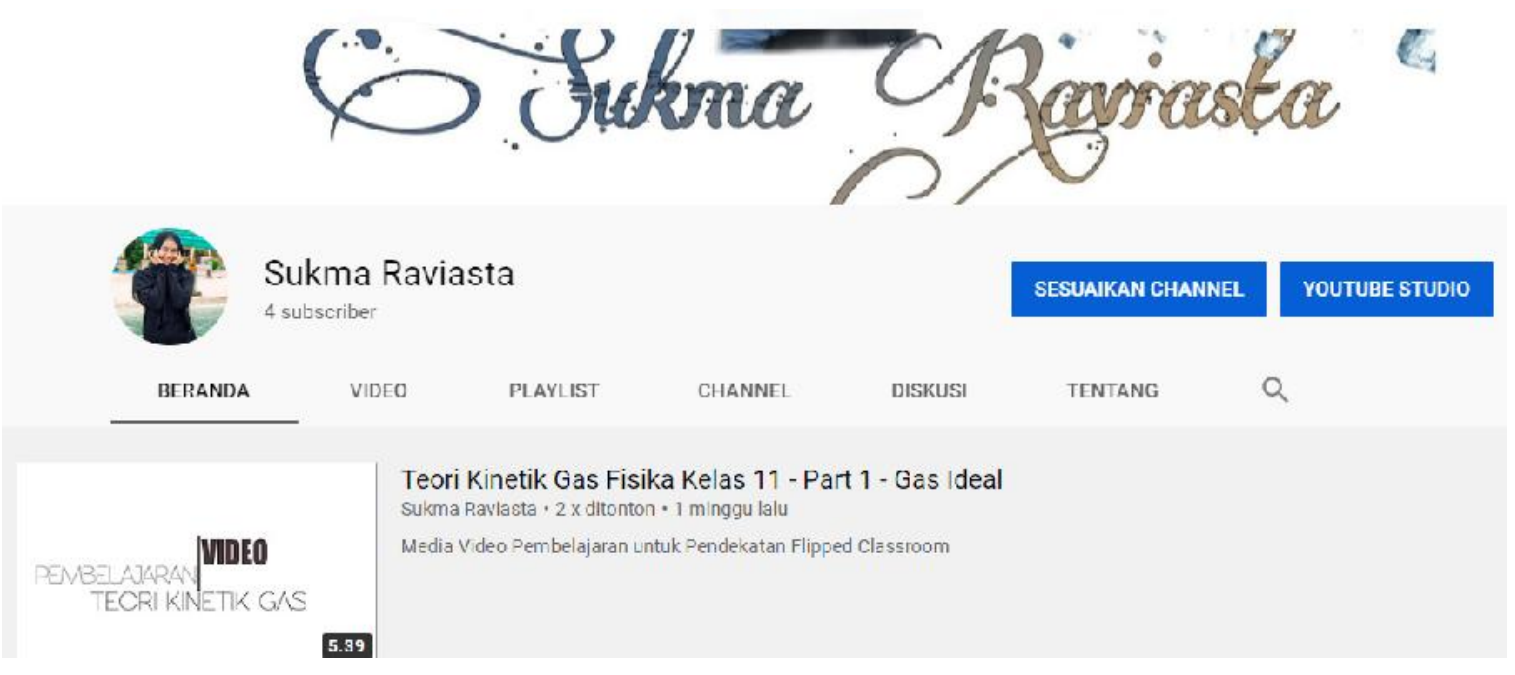

Gambar 1. Channel you tube Sukma Raviasta.

Judul video pembelajaran yang digunakan dengan pendekatan flipped classroom:

Video 1: Teori Kinetik Gas Fisika Kelas 11 - Part 1, (https://youtu.be/hG7yJPs9bI)

Video 2: Teori Kinetik Gas Fisika Kelas 11 - Part 2, (https://youtu.be/dalWQS4faG)

Video 3: Teori Kinetik Gas Fisika Kelas 11 - Part 3, (https://youtu.be/uISsaBVh8U)

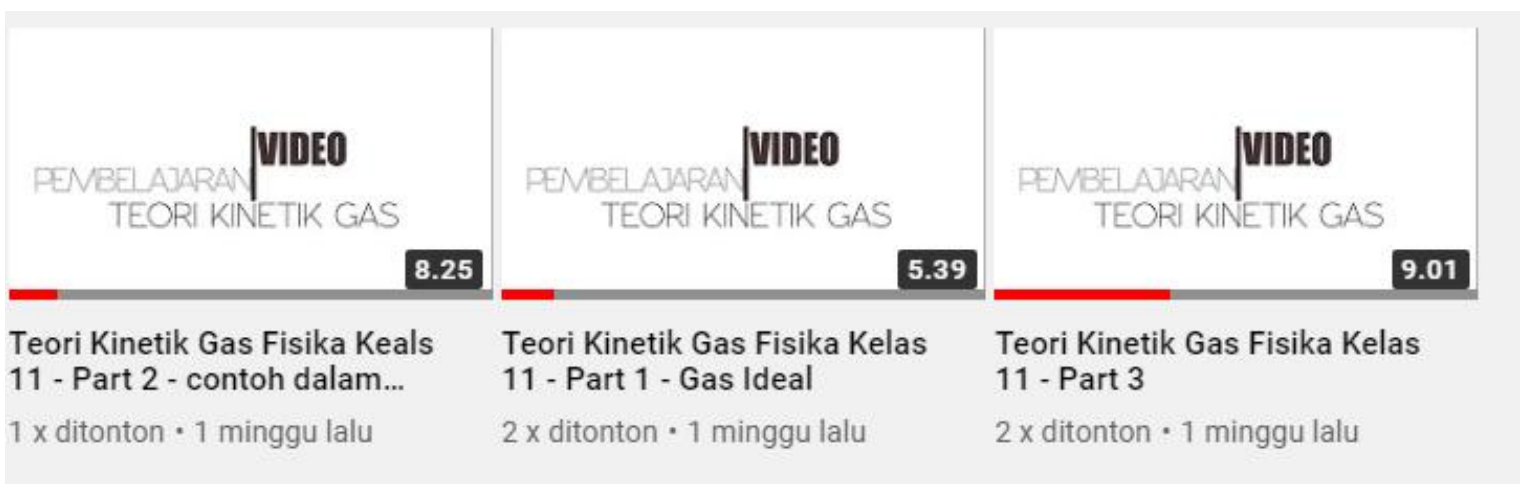

Gambar 2. Video pembelajaran teori kinetik gas. 
Validasi RPP yang sudah dikembangkan dikelompokkan kedalam 8 aspek yaitu: aspek kesesuaian KD, indikator, dan alokasi waktu, aspek tujuan pembelajaran, aspek materi pembelajaran, aspek metode pembelajaran, aspek sumber belajar, aspek kegiatan pembelajaran, aspek media pembelajaran dan, aspek penilaian. Hasil rata-rata perolehan seluruh aspek RPP dapat dilihat pada Tabel 5.

Tabel 5. Rata-rata penilaian aspek RPP dengan pendekatan flipped classroom

\begin{tabular}{lccc}
\hline \multicolumn{1}{c}{ Aspek } & Skor & $\begin{array}{c}\text { Kate- } \\
\text { gori }\end{array}$ & Validitas \\
\hline $\begin{array}{l}\text { Kesesuaian KD, } \\
\text { Indikator, dan }\end{array}$ & 4,5 & ST & Valid \\
$\begin{array}{l}\text { Alokasi Waktu } \\
\text { Tujuan }\end{array}$ & & & \\
$\begin{array}{l}\text { Pembelajaran } \\
\text { Materi }\end{array}$ & 4,2 & ST & Valid \\
$\begin{array}{l}\text { Pembelajaran } \\
\text { Metode }\end{array}$ & 4,4 & ST & Valid \\
$\begin{array}{l}\text { Pembelajaran } \\
\text { Media }\end{array}$ & 4,3 & ST & Valid \\
$\begin{array}{l}\text { Pembelajaran } \\
\text { Sumber Belajar }\end{array}$ & 4,3 & ST & Valid \\
$\begin{array}{l}\text { Kegiatan } \\
\text { Pembelajaran }\end{array}$ & 4,45 & ST & Valid \\
Penilaian & 4,4 & ST & Valid \\
\hline Rata-Rata & 4,4 & ST & Valid \\
\hline Ket ST Sa ST & ST & Valid \\
\hline
\end{tabular}

Ket. ST = Sangat Tinggi.

Berdasarkan Tabel 5 rata-rata skor untuk keseluruhan aspek oleh validator 4,36 dari skala 5 dengan kategori ST (sangat tinggi) dan nilai validitas dinyatakan valid. Hasil validasi yang dilakukan pada RPP dengan pendekatan flipped classroom telah dilakukan perbaikan, sehingga dinyataakan valid dan layak untuk digunakan dalam proses belajar mengajar dengan kategori sangat tinggi. Hasil analisis dari keseluruhan aspek penilaian yang seirama dengan penelitian Eko (2014) dimana rencana pelaksanaan pembelajaran (RPP) dinyatakan valid dan layak untuk digunakan sebagai perangkat pembelajaran dengan nilai rata-rata 3,8 dari skala 4. RPP dengan pendekatan flipped classroompada saat di luar kelas digunakan untuk menonton video pembelajaran yang diberikan, dan ketika di dalam kelas diberikan latihan soal seperti yang biasa dilakukan untuk memberi peserta didik pekerjaan rumah dan memecahkan masalah yang dapat dibimbing oleh guru (Bioshop \& Verleger, 2013).

Video pembelajaran sebagai media pembelajaran untuk pendekatan flipped classroom yang sudah dikembangkan divalidasi oleh 3 validator dari dosen Pendidikan Fisika yang ahli dibidangnya. Berdasarkan analisis data validasi diperoleh hasil analisis sebagaiman pada Tabel 6. Hasil analisis ini berdasarkan skor validitas video pembelajaran yang diberikan oleh validator setelah direvisi.

Tabel 6 memperlihatkan bahwa skor validasi dari validator diperoleh skor tertinggi 5 pada indikator penilaian nomor 6,7 , dan 13 . Terdapat indikator penilaian yang mendapat skor 4,6 yaitu indikator nomor 1, 2, 3, 4, 8, 10, dan 15. Indikator penilaian dengan nilai 4,3 yaitu pada indikator nomor $5,11,12$, dan 14 . Sementara skor terendah adalah 4 yaitu pada indikator nomor 9. Rata-rata yang didapatkan dari keseluruhan indikator pada video pembelajaran adalah 4,56 yang berada pada kategori ST (sangat tinggi) dengan nilai validitas valid. Hasil validasi yang dilakukan pada video pembelajaran telah mengalami perbaikan sehingga dikatakan layak untuk digunakan dalam proses belajar. Hal ini juga sejalan dengan penelitian yang dilakukan oleh Suryani (2012), aspek penilaian secara menyeluruh diperoleh penilaian $85,06 \%$ yang termasuk dalam kualifikasi sangat baik.

Menurut Warsihna (2010) pada modul pelatihan pembuatan video, media video harus mampu menampilkan gambar dengan gerak, serta suara secara bersamaan dengan baik, pada penelitian ini tergambar dengan hasil skor penilaian yang diberikan oleh validator adalah 5, dimana 5 merupakan poin maksimal yang berarti video memiliki kualitas gambar dan suara yang sangat baik. Video sebagai media pembelajaran yang telah dikembangkan untuk pembelajaran sebelum kelas dimulai dapat digunakan peserta didik sebagai sumber belajar di rumah ( Wolff \& Chan, 2016). Video pembelajaran juga mampu menampilkan bentuk benda yang sangat tidak mungkin ke dalam kelas karena terlalu besar (gunung), terlalu kecil (kuman), terlalu abstrak (bencana), terlalu rumit (proses produksi), terlalu jauh (kehidupan di kutub) serta memungkinkan adanya rekayasa (animasi) (Warsihna, 2010). Oleh karena itu, peserta 
Tabel 6. Penilaian aspek video pembelajaran dengan pendekatan flipped classroom

\begin{tabular}{|c|c|c|c|c|}
\hline \multirow{2}{*}{ No } & \multirow{2}{*}{ Indikator Penilaian } & \multicolumn{3}{|c|}{ Skor validasi } \\
\hline & & Rata-rata & Kategori & Nilai Validitas \\
\hline 1 & $\begin{array}{l}\text { Video pembelajaran dengan pendekatan Flipped } \\
\text { Classroom disajikan sesuai silabus dan RPP }\end{array}$ & 4,6 & ST & Valid \\
\hline 2 & $\begin{array}{l}\text { Kesesuaian soal video pembelajaran dengan } \\
\text { kompetensi dasar }\end{array}$ & 4,6 & ST & Valid \\
\hline 3 & $\begin{array}{l}\text { Kesesuaian video pembelajaran dengan } \\
\text { indikator dan tujuan pembelajaran }\end{array}$ & 4,6 & ST & Valid \\
\hline 4 & $\begin{array}{l}\text { Bahasa yang digunakan pada video sesuai } \\
\text { dengan indikator berfikir siswa }\end{array}$ & 4,6 & ST & Valid \\
\hline 5 & $\begin{array}{l}\text { Bahasa yang digunakan dalam video sesuai } \\
\text { EYD }\end{array}$ & 4,3 & ST & Valid \\
\hline 6 & Kualitas gambar video baik & 5 & ST & Valid \\
\hline 7 & Kualitas suara yang baik & 5 & ST & Valid \\
\hline 8 & Perpaduan gambar yang sesuai & 4,6 & ST & Valid \\
\hline 9 & Animasi yang representative dan menarik & 4 & $\mathrm{~T}$ & Valid \\
\hline 10 & Durasi waktu video sesuai kebutuhan & 4,6 & ST & Valid \\
\hline 11 & $\begin{array}{l}\text { Penyajian materi yang meningkatkan minat } \\
\text { belajar siswa }\end{array}$ & 4,3 & ST & Valid \\
\hline 12 & Penyajian materi yang mudah dipahami & 4,3 & ST & Valid \\
\hline 13 & $\begin{array}{l}\text { Meningkatkan pengetahuan siswa pada materi } \\
\text { yang dipelajari }\end{array}$ & 5 & ST & Valid \\
\hline 14 & $\begin{array}{l}\text { Dengan video pembelajaran meningkatkan } \\
\text { keefektifan siswa dalam belajar }\end{array}$ & 4,3 & ST & Valid \\
\hline 15 & $\begin{array}{l}\text { Materi yang disampaikan sesuai dengan } \\
\text { perkembangan teknologi }\end{array}$ & 4,6 & ST & Valid \\
\hline & Rata-Rata Skor & 4,56 & ST & Valid \\
\hline
\end{tabular}

Ket. ST = Sangat Tinggi.

didik mampu memahami materi dan dapat memahami dengan mudah penerapan teori kinetik gas dalam kehidupan sehari-hari.

Lembar kerja peserta didik (LKPD) dengan pendekatan flipped classroom yang sudah dikembangkan dan divalidasi oleh 3 validator diperoleh hasil analisisnya berdasarkan hasil skor validitas LKPD yang diberikan oleh validator setelah setelah direvisi, dapat dilihat pada Tabel 7.

Tabel 7 memperlihatkan bahwa skor validasi dari validator mendapatkan skor tertinggi 4,6 pada indikator penilaian nomor 2. Terdapat indikator penilaian yang mendapat skor 4,3 yaitu indikator nomor $1,3,8$, dan 9 .
Sementara skor terendah 4 yaitu pada indikator nomor 4, 5, 6, dan 7. Rata-rata yang didapatkan dari keseluruhan indikator pada LKPD adalah 4,2 yang berada pada kategori ST (sangat tinggi) dan nilai validitas valid. Hasil validasi yang dilakukan pada LKPD telah mengalami perbaikan, sehingga dikatakan layak untuk digunakan dalam proses belajar mengajar dengan kategori sangat tinggi. Trianto (2010) menyatakan LKPD adalah panduan untuk melakukan kegiatan penyelidikan atau pemecahan masalah. Lembar ini dapat berupa panduan untuk latihan aspek kognitif, panduan praktikum, maupun panduan demonstrasi. 
Tabel 7. Rata-rata Penilaian Aspek LKPD dengan pendekatan flipped classroom

\begin{tabular}{|c|c|c|c|c|}
\hline \multirow[b]{2}{*}{ No. } & \multirow[b]{2}{*}{ Indikator Penilaian } & \multicolumn{3}{|c|}{ Skor validasi } \\
\hline & & Rata-rata & Kategori & $\begin{array}{l}\text { Kategori } \\
\text { Validitas }\end{array}$ \\
\hline 1 & $\begin{array}{l}\text { Kegiatan LKPD yang berbasis pendekatan } \\
\text { Flipped Classroom disajikan sesuai silabus dan } \\
\text { RPP }\end{array}$ & 4,3 & ST & Valid \\
\hline 2 & Kesesuaian soal LKPD dengan kompetensi dasar & 4,6 & ST & Valid \\
\hline 3 & $\begin{array}{l}\text { Kesesuaian soal LKPD dengan indikator dan } \\
\text { tujuan pembelajaran }\end{array}$ & 4,3 & ST & Valid \\
\hline 4 & Bahasa yang digunakan dalam LKPD sesuai EYD & 4,0 & $\mathrm{~T}$ & Valid \\
\hline 5 & $\begin{array}{l}\text { Bahasa yang digunakan pada LKPD sesuai } \\
\text { dengan tingkat berfikir siswa }\end{array}$ & 4,0 & $\mathrm{~T}$ & Valid \\
\hline 6 & LKPD menarik dan memotivasi & 4,0 & $\mathrm{~T}$ & Valid \\
\hline 7 & Konsistensi penyajian LKPD & 4,0 & $\mathrm{~T}$ & Valid \\
\hline 8 & $\begin{array}{l}\text { Tersedia ruang yang cukup untuk menuliskan } \\
\text { jawaban }\end{array}$ & 4,3 & ST & Valid \\
\hline \multirow[t]{2}{*}{9} & $\begin{array}{l}\text { Huruf untuk topik, dengan informasi atau } \\
\text { instruksi telah jelas bedanya }\end{array}$ & 4,3 & ST & Valid \\
\hline & Rata-rata skor & 4,2 & ST & Valid \\
\hline
\end{tabular}

Ket. T= Tinggi; ST $=$ Sangat Tinggi.

Lembar kerja peserta didik adalah lembarlembar berisi tugas. Hal ini juga sejalan dengan penelitian yang dilakukan oleh Ango (2013), yang hasil penilaian LKPD nya memiliki rata-rata skor dari ahli media dan materi adalah 83,25\% dengan kategori baik. Dalam Sholeh (2013) manfaat yang diperoleh dengan penggunaan LKPD adalah peserta didik diharapkan dapar aktif dalam pembelajaran, LKPD dapat membantu dan melatih peserta didik dalam mengembangkan konsep dan keterampilan proses serta membantu peserta didik memperoleh materi yang dipelajari.

\section{Kesimpulan}

Berdasarkan hasil dan pembahasan dari penelitian ini, maka dapat disimpulkan bahwa telah dihasilkan perangkat pembelajaran dengan pendekatan flipped classroom berupa RPP dan LKPD serta video pembelajaran. Validitas RPP, LKPD, dan video pembelajaran memperoleh skor rata-rata sangat tinggi dengan nilai validitas dinyatakan valid.
Validitas RPP semua aspek penilaian mendapat skor rata-rata sangat tinggi. Validitas LKPD dan video pembelajaran mendapat skor rata-rata sangat tinggi bahkan pada indikator penilaian suara dan gambar pada video pembelajaran mendapatkan skor maksimal. Dengan demikian perangkat pembelajaran dengan pendekatan flipped classroom pada materi teori kinetik gas untuk peserta didik kelas XI MIPA Sekolah Menengah Atas dinyatakan valid dan layak digunakan.

\section{Daftar Pustaka}

Alfrado, W. S., Rahmad, M., Syafii, M., \& Nurliana. (2018). Pengembangan Blog Pembelajaran Fisika Berbasis Pendekatan Flipped Classroom untuk Siswa Kelas X MIPA Sekolah Menengah Atas. Jurnal Geliga Sains, 6(2), 75-84.

Ango, B. 2013. Pengembangan Lembar Kerja Peserta Didik (LKPD) Mata Pelajaran Teknologi Informasi Dan Komunikasi Berdasarkan Standar Isi Untuk Sma Kelas 
X Semester Gasal. Yogyakarta: Universitas Negri Yogyakarta.

Azhar, A. (2011). Media Pembelajaran. Jakarta: PT Raja Grafindo Persada.

Bergman, J. A., \& Sams. (2012). Flip Your Classroom: Reach Every Student in Every Class Every Day. United States: The International Society.

Bioshop, J. L., \& Verleger, M. A. (2013). The Flipped Classroom: A Survey of the Research. Atlanta: 120th ASEE Annual Conference \& Exposition.

BNSP. (2003). Undang-Undang Nomor 20 tahun 2003 tentang Sistem Pendidikan Nasional. Jakarta : BSNP, Republik Indonesia.

Brent, J. G. (2013). Student Perception of The Flipped Classroom. Thesis. https://pdfs. semanticscholar.org/a3ae/d2f5af55e65124 d3369c3a605313e16a8ef7.pdf (diakses pada 10 Februari 2020).

Djaali \& Pudji, M. (2008). Pengukuran dalam Bidang Pendidikan. Jakarta: Program Pasca Sarjana UNJ.

Hefzallah, I. M. (2004). The New Educational Technologies and Learning, Springfield, Illionis, USA: Charles C. Thomas Publisher.

Jaka, A. (2016). Penggunaan Multimedia dalam Pembelajaran Teori Kinetik Gas di Sma/Ma Negeri dan Swasta Kecamatan Sambas. Jurnal Pendidikan dan Matematika IPA Vol. 4. No. 2. www.jurnal.unta.ac.id (diakses pada 10 Februari 2020).

Ozdamli, F., \& Asiksoy, G. (2016). Flipped Classroom Approach. World Journal on Educational Technology: Current Issues. 8(2), 98-105.

Saputra, M. E. A. (2018). Efektifitas Model Flipped Classroom Menggunakan Video Pembelajaran Matematika terhadap Pemahaman konsep. JOM, 1(2), Universitas Islam Raden Intan Lampung. https://ejournal.radenintan.ac.id/ (diakses pda 9 Februari 2020).

Saputro, P. E., Nur, M., \& Sumbawati, M. S. (2014). Pengembangan Perangkat Pembelajaran Kooperatif Jigsaw Untuk Mengajarkan Materi Efek Video Pada Kompetensi Dasar Melaksanakan Editing Kelas X Smk Negeri 1 Surabaya. Surabaya. Universitas Negeri Surabaya. Jurnal Pendidikan Vokasi: Teori dan
Praktek. https://media.neliti.com/media/ publications/246730-pengembanganperangkat-pembelajaran-koop39ab33a4.pdf

Sholeh, H. (2013). Pengembangan Kurikulum Baru. Bandung: PT. Remja Rosdakarya.

Suryani, I. (2012). Pengembangan Video Pembelajaran Menggunakan Model Problem Solving Berbantu Wondershare pada Materi Statistika di SMP. 1-13.

https://media.neliti.com/media/publication s/176758-ID-pengembangan-videopembelajaran-mengguna.pdf

Sugiyono. (2012). Metode Penelitian Kuantitatif Kualitatif dan $R \& D$. Bandung: CV Alfabeta.

Trianto. (2010). Mendesain Pendekatan Pembelajaran Inovatif-Progresif. Jakarta: Kencana.

Warsihna, J. (2010). Modul Pelatihan Pengembangan dan Pemanfaatan Konten Jardiknas: Pembuatan Media Video. Kementerian Pendidikan Nasional Pusat Teknologi Informasi dan Komunikasi Pendidikan.

Wolff. L. C., \& Chan, J. (2016). Erratum to: Flipped Classrooms for Legal Education. Hongkong: Springer.

Yunita. D., \& Wijayanti. (2017). Pengaruh Media Video Pembelajaran terhadap Hasil Belajar IPA Ditinjau dari Keaktifan Siswa. 3(2). www.jurnalustjogja.ac.id (diakses pada 25 Februari 2020). 